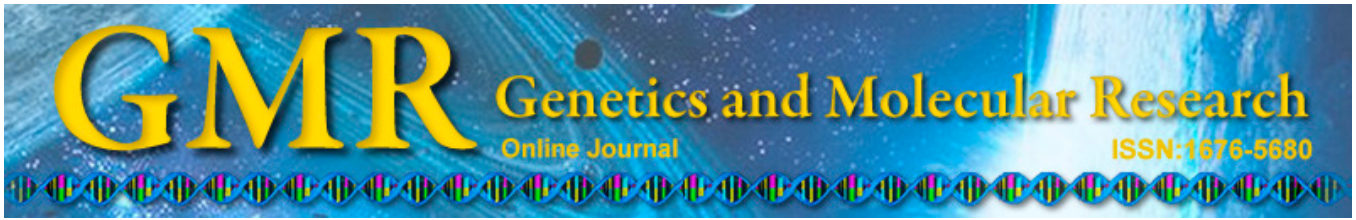

\title{
Association of PTPN22 gene polymorphism with type 1 diabetes mellitus in Chinese children and adolescents
}

\author{
H.W. Liu ${ }^{1}$, R.Y. Xu ${ }^{1}$, R.P. Sun ${ }^{1}$, Q. Wang ${ }^{2}$, J.L. Liu ${ }^{1}$, W. Ge ${ }^{1}$ and Z. Yu ${ }^{1}$ \\ ${ }^{1}$ Department of Pediatrics, Qilu Hospital of Shandong University, Jinan, China \\ ${ }^{2}$ Department of Anesthesiology, Qingdao Municipal Hospital, Qingdao, China \\ Corresponding author: H.W. Liu \\ E-mail: liuhuawei1900@yeah.net
}

Genet. Mol. Res. 14 (1): 63-68 (2015)

Received March 18, 2014

Accepted November 25, 2014

Published January 15, 2015

DOI http://dx.doi.org/10.4238/2015.January.15.8

\begin{abstract}
Previous studies have indicated that the protein tyrosine phosphatase nonreceptor type 22 gene (PTPN22) is associated with type 1 diabetes (T1DM) in the Caucasian population. In the present study, we investigated the relationship between PTPN22 genetic polymorphisms and T1DM in Chinese children. A total of 202 children and adolescents with T1DM and 240 healthy control subjects of Chinese Han origin were included in our analysis. Polymerase chain reaction-restriction fragment length polymorphism was used to determine the presence of the C1858T polymorphism in the PTPN22 gene. We found that the TT $+\mathrm{TC}$ genotype and the $\mathrm{T}$ allele of $\mathrm{C} 1858 \mathrm{~T}$ were more frequent in T1DM patients (19.40 and $10.0 \%$, respectively) than in healthy subjects $(7.51$ and $4.0 \%$, respectively), and the difference was significant (both $\mathrm{P}<$ 0.001). After adjusting for confounding variables such as gender, age, and family history of T1DM, the difference remained significant $(\mathrm{P}$ $=0.007$, odds ratio $=2.88,95 \%$ confidence interval 1.76-4.32). Our results indicate that genetic polymorphisms in the PTPN22 gene may increase the risk of T1DM in Chinese children and adolescents.
\end{abstract}

Key words: Adolescent; Children; Type 1 diabetes mellitus; PTPN22 


\section{INTRODUCTION}

Type 1 diabetes mellitus (T1DM) is the second most common chronic childhood disease. The prevalence of T1DM accounts for 5-10\% of all diabetes cases (Gale, 2002; Awoniyi et al., 2013; Lipman et al., 2013). Although the exact pathogenesis of T1DM is unknown, T1DM is thought to involve multifactor disorders resulting from genetic polymorphisms as well as various environmental factors (Rich et al., 2006; Ei Wafai et al., 2011; Pehlić et al., 2012; Hadžija et al., 2013). Previous studies have indicated that genetic polymorphisms in genes such as TRAIL (Bernardi et al., 2012), HLA (Black and Dabelea, 2013), and CCR5 (Yang et al., 2004) were associated with T1DM risk. However, these results do not fully explain the susceptibility to T1DM.

Protein tyrosine phosphatase non-receptor type 22 (PTPN22), a powerful negative regulator of T-cell activation, has been associated with several autoimmune diseases, such as systemic lupus erythematosus (Namjou et al., 2013), T1DM (Giza et al., 2013), juvenile idiopathic arthritis (Dimopoulou et al., 2013), autoimmune thyroid disease (Alkhateeb et al., 2013), and rheumatoid arthritis (Taylor et al., 2013).

PTPN22, which is located on chromosome 1, encodes the lymphoid specific tyrosine phosphatase protein Lyp. Lyp is composed of 807 amino acids and plays a major role in regulating the Src family of tyrosine kinases. Src family tyrosine kinases act as a molecular switch to regulate various cellular events, including cell growth, division, differentiation, and programmed death (Reddy et al., 2005).

Recently, the C1858T polymorphism in PTPN22 was reported to be associated with T1DM in a Caucasian population (Bottini et al., 2004). However, this association was not observed in a Greek population (Giza et al., 2013) or in Japanese subjects (Taniyama et al., 2010). C1858T in PTPN22 was also associated with T1DM in a recent meta-analysis (Tang et al., 2012); however, the relationship between the C1858T variant and T1DM in Chinese children and adolescents remains unknown.

In this study, we investigated the association between a genetic polymorphism and T1DM in Chinese children and adolescents.

\section{MATERIAL AND METHODS}

\section{Subjects}

We selected 202 children (3-12 years) and adolescents (13-18 years) (121 male, 81 female) with T1DM and 240 age- and gender-matched healthy control subjects (149 male, 91 female) of Chinese Han origin form May 2011 to July 2013. The mean age of participants was $12.01 \pm 2.11$ years. All patients were diagnosed with T1DM before the age of 15 years and were insulin-dependent. The control group included children and adolescents without T1DM and no family history of T1DM. Informed consent was obtained from parents or guardians of individuals younger than 18 years. The research protocol was conducted in accordance with the Declaration of Helsinki and was approved by the Ethics Committee of Faculty of Qilu Hospital, Shandong University.

\section{Methods}

Peripheral blood was collected in a test tube containing ethylenediaminetetraacetic 
acid (EDTA) as an anticoagulant. DNA was isolated using a DNA Extraction Kit for blood (Bioteke Inc.; Beijing, China) according to the manufacturer protocol. The primers have been described previously (Giza et al., 2013): forward 5'-ACTGATAATGTTGCTTCAACGG-3' and reverse 5'-TCACCAGCTTCCTCAACCAC-3'. The genotyping method was performed according to a previously described protocol (Giza et al., 2013). Briefly, the $40-\mu \mathrm{L}$ polymerase chain reaction (PCR) included $4 \mu \mathrm{L} 10 \mathrm{X}$ reaction buffer, $3.2 \mu \mathrm{L} \mathrm{Mg}^{2+}, 3.8 \mu \mathrm{L}$ dNTPs, $0.5 \mu \mathrm{L}$ upstream primer, $0.5 \mu \mathrm{L}$ downstream primer, $0.3 \mu \mathrm{L}$ Taq enzyme, $28.7 \mu \mathrm{L} \mathrm{ddH}_{2} \mathrm{O}$, and $2.0 \mu \mathrm{L}$ DNA. The PCR conditions were as follows: $94^{\circ} \mathrm{C}$ initial denaturation for $3 \mathrm{~min}$, $94^{\circ} \mathrm{C}$ denaturation for $15 \mathrm{~s}, 57^{\circ} \mathrm{C}$ annealing for $30 \mathrm{~s}$, and $72^{\circ} \mathrm{C}$ extension for $30 \mathrm{~s}$. After 35 cycles, we conducted a final extension step at $72^{\circ} \mathrm{C}$ for $10 \mathrm{~min}$ and the reaction was held at $12^{\circ} \mathrm{C}$ for conservation. A restriction fragment length polymorphism method was used to identify the presence of the target polymorphism, C1858T. The enzymatic system (20 $\mu \mathrm{L}$ ) included $2 \mu \mathrm{L}$ NEB4 Buffer (New England Biolabs; Ispwich, MA, USA), $0.5 \mu \mathrm{L} R s a \mathrm{I}$ enzyme (Fermentas; Vilnius, Lithuania), $7.5 \mu \mathrm{L}$ purified PCR products, and $10 \mu \mathrm{L} \mathrm{ddH}_{2} \mathrm{O}$. PCR products were incubated in a $37^{\circ} \mathrm{C}$ water bath for $3 \mathrm{~h}$. Next, $10 \mu \mathrm{L}$ enzyme-digested product was analyzed by electrophoresis on a $1.5 \%$ agarose gel. The enzyme cuts the $\mathrm{C}$ allele into 2 fragments of 172 base pairs (bp) and $46 \mathrm{bp}$, while the $\mathrm{T}$ allele allows the fragment to remain intact (218 bp).

\section{Statistical analysis}

The SPSS 17.0 software (SPSS Institute; Chicago, IL, USA) was used for data analysis. Hardy-Weinberg equilibrium was evaluated using the chi-square test; differences in frequencies of genotypes and alleles between patients and controls were analyzed by chisquare or Fisher's exact tests. Statistical significance was defined as $\mathrm{P}<0.05$.

\section{RESULTS}

The distribution of genotypes in patients and controls was found to be in HardyWeinberg equilibrium (both $\mathrm{P}>0.05$ ). The characteristics of the participants are shown in Table 1. There were significant differences between the T1DM group and the control group in family history, body mass index, glucose, triglycerides, total cholesterol, and low-density lipoprotein-cholesterol (all $\mathrm{P}<0.01$ ). We found no significant difference between groups in gender ratio, age, and high-density lipoprotein-cholesterol (all $\mathrm{P}>0.05)$. The frequency of the $\mathrm{T}$ allele was higher in patients than in controls $(10.0$ vs $4.0 \%$; $\mathrm{P}<0.001$, odds ratio (OR) $=2.81,95 \%$ confidence interval $(\mathrm{CI}=1.59-4.95)$. A significant difference was observed between patients and control subjects in the $\mathrm{CT}$ genotype distribution $(\mathrm{P}<0.001)$. However, we found no significant difference between these 2 groups in the TT genotype frequency. Because of the relatively low frequency of the T allele, the CT and TT genotypes were grouped together for statistical analysis. We observed the TT $+\mathrm{CT}$ genotype and $\mathrm{T}$ allele more frequently in T1DM patients (19.40 and $10.0 \%$, respectively) than in healthy subjects (7.51 and 4.0\%, respectively), and the difference was significant (both $\mathrm{P}<0.001$ ) (Table 2). After adjusting for other confounders such as gender, age, family history of T1DM, and lipid profiles, the difference remained significant $(\mathrm{P}=0.007, \mathrm{OR}=2.88,95 \% \mathrm{CI}=1.76-4.32)$ (Table 3). 


\begin{tabular}{|c|c|c|c|c|c|c|c|c|c|c|}
\hline Groups & $\mathrm{N}$ & $\begin{array}{c}\text { Gender ratio } \\
\text { (Male/Female) }\end{array}$ & $\begin{array}{c}\text { Age } \\
\text { (years) }\end{array}$ & $\begin{array}{c}\text { Family history } \\
(\mathrm{N}=\%)\end{array}$ & $\begin{array}{c}\text { BMI } \\
\left(\mathrm{Kg} / \mathrm{m}^{2}\right)\end{array}$ & $\begin{array}{l}\text { GLU } \\
(\mathrm{mM})\end{array}$ & $\begin{array}{c}\text { TG } \\
(\mathrm{mM})\end{array}$ & $\begin{array}{c}\mathrm{TC} \\
(\mathrm{mM})\end{array}$ & $\begin{array}{c}\text { HDL-C } \\
(\mathrm{mM})\end{array}$ & $\begin{array}{l}\text { LDL-C } \\
(\mathrm{mM})\end{array}$ \\
\hline T1DM group & 229 & $136 / 93$ & $13.3 \pm 1.02$ & $47(20.52)$ & $20.8 \pm 2.7$ & $4.52 \pm 0.49$ & $0.61 \pm 0.27$ & $2.85 \pm 0.68$ & $0.89 \pm 0.22$ & $1.45 \pm 0.49$ \\
\hline $\begin{array}{l}\text { Control group } \\
\text { P }\end{array}$ & 213 & $115 / 98$ & $13.9 \pm 1.01$ & $15(7.04)$ & $17.2 \pm 1.5$ & $4.32 \pm 0.43$ & $0.52 \pm 0.17$ & $2.64 \pm 0.56$ & $0.90 \pm 0.21$ & $1.27 \pm 0.34$ \\
\hline$P$ & & 0.291 & 0.102 & $<0.001$ & $<0.001$ & $<0.001$ & $<0.001$ & $<0.001$ & 0.893 & $<0.001$ \\
\hline
\end{tabular}

$\mathrm{T} 1 \mathrm{DM}=$ type 1 diabetes mellitus; $\mathrm{BMI}=$ body mass index; $\mathrm{GLU}=$ blood glucose; $\mathrm{TG}=$ triglyceride; $\mathrm{TC}=$ total cholesterol; HDL-C = high-density lipoprotein cholesterol; LDL-C = low=density lipoprotein cholesterol.

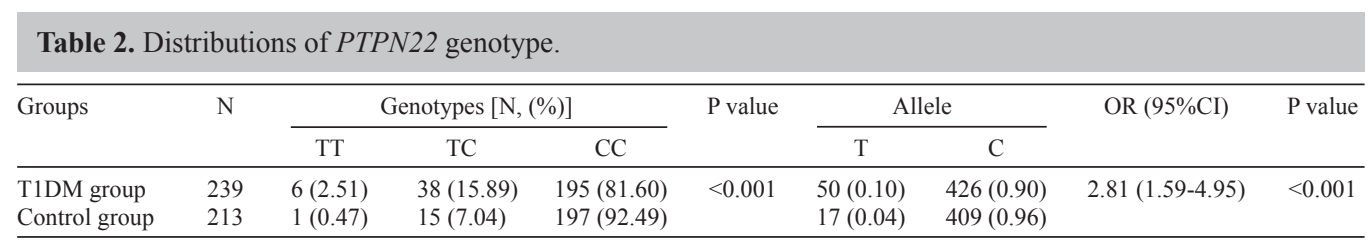

$\mathrm{T} 1 \mathrm{DM}=$ type 1 diabetes mellitus.

Table 3. Results of logistic regression.
\begin{tabular}{lccccc}
\hline Variables & B & S.E. & Wald & P value & OR (95\%CI) \\
\hline Age & 1.121 & 0.076 & 4.123 & 0.011 & $1.44(1.01-3.12)$ \\
Gender & -0.231 & 0.233 & 2.132 & 0.121 & $0.87(0.13-1.66)$ \\
Family history & 2.322 & 0.674 & 4.127 & 0.010 & $2.18(1.45-3.43)$ \\
T allele & 1.242 & 0.012 & 5.329 & 0.007 & $2.88(1.76-4.32)$ \\
\hline
\end{tabular}

\section{DISCUSSION}

In the present study, we found that a polymorphism in the PTPN22 gene was associated with T1DM in Chinese children and adolescents. This is the first study to identify the relationship between the PTPN22 gene polymorphism and T1DM in Chinese children and adolescents.

The PTPN22 gene, which encodes Lyp, is located on chromosome 1p13.3-p13.1. Lyp inhibits the activation and proliferation of T lymphocytes, and genetic variants in PTPN22 may result in the reduction or inactivation of Lyp function. Currently, there are 1073 singlenucleotide polymorphisms of PTPN22 listed in the NCBI database (http://www.ncbi.nlm.nih. gov/snp); rs2476601, which is at position 1858 in the coding region of the PTPN22 gene, results in substitution of arginine with tryptophan at codon 620 of Lyp (Yu et al., 2007). This mutation may interfere with the Lyp-Csk interaction (Yu et al., 2007), leading to uncontrolled T-cell receptor signaling and inappropriate prolonged activation of T lymphocytes (Yu et al., 2007). This may be the mechanism linking C1858T variants with the risk for T1DM.

Various recent publications have reported a relationship between PTPN22 and T1DM (Bottini et al., 2004; Kahles et al., 2005; Zheng and She, 2005; Steck et al., 2006; Nielsen et al., 2007; Smyth et al., 2004, 2008; Petrone et al., 2008; Saccucci et al., 2008; Dultz et al., 2009). Bottini et al. (2004) were the first to report an association between the PTPN22 polymorphism and T1DM. However, in their study, the participants were from North America and Sardinia. Recently, several studies involving different populations have explored the relationship between PTPN22 and T1MD, including studies from Italy (Petrone et al., 2008; Saccucci et al., 2008), Spain (Santiago et al., 2007), Denmark (Nielsen et al., 2007), North America 
(Zheng and She, 2005; Steck et al., 2006), Ukraine (Fedetz et al., 2006), Estonia (Douroudis et al., 2008), Finland (Hermann et al., 2006), the Netherlands (Zhernakova et al., 2005), France (Chelala et al., 2007), Croatia (Korolija et al., 2009), Germany (Kahles et al., 2005; Dultz et al., 2009), Russia (Zhebrun et al., 2011), Colombia (Gomez et al., 2005), Norway (Stene et al., 2010), Poland (Fichna et al., 2010), the United Kingdom (Smyth et al., 2004, 2008), the Czech Republic and Azerbaijan (Cinek et al., 2007), India (Baniasadi and Das, 2008), and Brazil (Chagastelles et al., 2010). However, there was disagreement among these studies regarding the relationship between PTPN22 and T1MD.

In this study, we investigated the role of PTPN22 polymorphisms in Chinese children and adolescents with T1DM. We observed the T allele more frequently in T1DM patients than in control subjects after adjusting for other confounders, indicating that the $\mathrm{T}$ allele is an independent risk factor for T1DM in Chinese children and adolescents.

In conclusion, our findings agree with the results of similar studies in other populations. However, additional studies including a larger sample are needed to confirm our results.

\section{Conflict of interests}

The authors declare no conflict of interest.

\section{REFERENCES}

Alkhateeb A, Marzouka NA and Tashtoush R (2013). Variants in PTPN22 and SMOC2 genes and the risk of thyroid disease in the Jordanian Arab population. Endocrine 44: 702-709.

Awoniyi O, Rehman R and Dagogo-Jack S (2013). Hypoglycemia in patients with type 1 diabetes: epidemiology, pathogenesis, and prevention. Curr. Diab. Rep. 13: 669-678.

Baniasadi V and Das SN (2008). No evidence for association of PTPN22 R620W functional variant C1858T with type 1 diabetes in Asian Indians. J. Cell Mol. Med. 12: 1061-1062.

Bernardi S, Norcio A, Toffoli B, Zauli G, et al. (2012). Potential role of TRAIL in the management of autoimmune diabetes mellitus. Curr. Pharm. Des. 18: 5759-5765.

Black MH and Dabelea D (2013). Genetics: new HLA variants could predict T1DM risk in African Americans. Nat. Rev. Endocrinol. 9: 570-571.

Bottini N, Musumeci L, Alonso A, Rahmouni S, et al. (2004). A functional variant of lymphoid tyrosine phosphatase is associated with type I diabetes. Nat. Genet. 36: 337-338.

Chagastelles PC, Romitti M, Trein MR, Bandinelli E, et al. (2010). Association between the 1858T allele of the protein tyrosine phosphatase nonreceptor type 22 and type 1 diabetes in a Brazilian population. Tissue Antigens 76: 144-148.

Chelala C, Duchatelet S, Joffret ML, Bergholdt R, et al. (2007). PTPN22 R620W functional variant in type 1 diabetes and autoimmunity related traits. Diabetes $56: 522-526$.

Cinek O, Hradsky O, Ahmedov G, Slavcev A, et al. (2007). No independent role of the $-1123 \mathrm{G}>\mathrm{C}$ and $+2740 \mathrm{~A}>\mathrm{G}$ variants in the association of PTPN22 with type 1 diabetes and juvenile idiopathic arthritis in two Caucasian populations. Diabetes Res. Clin. Pract. 76: 297-303.

Dimopoulou DG, Zervou MI, Trachana M, Myrthianou E, et al. (2013). Investigation of juvenile idiopathic arthritis susceptibility loci: results from a Greek population. Hum. Immunol. 74: 1194-1198.

Douroudis K, Prans E, Haller K, Nemvalts V, et al. (2008). Protein tyrosine phosphatase non-receptor type 22 gene variants at position 1858 are associated with type 1 and type 2 diabetes in Estonian population. Tissue Antigens 72: 425-430.

Dultz G, Matheis N, Dittmar M, Röhrig B, et al. (2009). The protein tyrosine phosphatase non-receptor type 22 C1858T polymorphism is a joint susceptibility locus for immunthyroiditis and autoimmune diabetes. Thyroid 19: 143-148.

Ei Wafai RJ, Chmaisse HN, Makki RF and Fakhoury H (2011). Association of HLA class II alleles and CTLA-4 polymorphism with type 1 diabetes. Saudi J. Kidney Dis. Transpl. 22: 273-281.

Fedetz M, Matesanz F, Caro-Maldonado A, Smirnov II, et al. (2006). The 1858T PTPN22 gene variant contributes to a genetic risk of type 1 diabetes in a Ukrainian population. Tissue Antigens 67: 430-433.

Fichna M, Zurawek M, Januszkiewicz-Lewandowska D, Fichna P, et al. (2010). PTPN22, PDCD1 and CYP27B1 polymorphisms and susceptibility to type 1 diabetes in Polish patients. Int. J. Immunogenet. 37: 367-372. 
Gale EA (2002). The rise of childhood type 1 diabetes in the 20th century. Diabetes 51: 3353-3361.

Giza S, Goulas A, Gbandi E, Effraimidou S, et al. (2013). The role of PTPN22 C1858T gene polymorphism in diabetes mellitus type 1: first evaluation in Greek children and adolescents. Biomed. Res. Int. 2013: 721604.

Gomez LM, Anaya JM, Gonzalez CI, Pineda-Tamayo R, et al. (2005). PTPN22 C1858T polymorphism in Colombian patients with autoimmune diseases. Genes Immun. 6: 628-631.

Hadžija MP, Korolija M, Jemin N, Pavković I, et al. (2013). Polymorphisms in the IL-18 and IL-12B genes and their association with the clinical outcome in Croatian patients with type 1 diabetes. Gene 512: 477-481.

Hermann R, Lipponen K, Kiviniemi M, Kakko T, et al. (2006). Lymphoid tyrosine phosphatase (LYP/PTPN22) Arg620Trp variant regulates insulin autoimmunity and progression to type 1 diabetes. Diabetologia 49: 1198-1208.

Kahles H, Ramos-Lopez E, Lange B, Zwermann O, et al. (2005). Sex-specific association of PTPN22 1858T with type 1 diabetes but not with Hashimoto's thyroiditis or Addison's disease in the German population. Eur. J. Endocrinol. 153: 895-899.

Korolija M, Renar IP, Hadzija M, Medvidovic EP, et al. (2009). Association of PTPN22 C1858T and CTLA-4 A49G polymorphisms with type 1 diabetes in Croatians. Diabetes Res. Clin. Pract. 86: e54-e57.

Lipman TH, Ratcliffe SJ, Cooper R and Levitt Katz LE (2013). Population-based survey of the prevalence of type 1 and type 2 diabetes in school children in Philadelphia. J. Diabetes 5: 456-461.

Namjou B, Kim-Howard X, Sun C, Adler A, et al. (2013). PTPN22 association in systemic lupus erythematosus (SLE) with respect to individual ancestry and clinical sub-phenotypes. PLoS One 8: e69404.

Nielsen C, Hansen D, Husby S and Lillevang ST (2007). Sex-specific association of the human PTPN22 1858T-allele with type 1 diabetes. Int. J. Immunogenet. 34: 469-473.

Pehlić M, Vrkić D, Skrabić V and Jerončić A (2012). IL12RB2 gene is associated with the age of type 1 diabetes onset in Croatian family trios. PLoS One 7: e49133.

Petrone A, Suraci C, Capizzi M, Giaccari A, et al. (2008). The protein tyrosine phosphatase nonreceptor 22 (PTPN22) is associated with high GAD antibody titer in latent autoimmune diabetes in adults: Non Insulin Requiring Autoimmune Diabetes (NIRAD) study 3. Diabetes Care 31: 534-538.

Reddy MV, Johansson M, Sturfelt G, Jonsen A, et al. (2005). The R620W C/T polymorphism of the gene PTPN22 is associated with SLE independently of the association of PDCD1. Genes Immun. 6: 658-662.

Rich SS, Concannon P, Erlich H, Julier C, et al. (2006). The type 1 diabetes genetics consortium. Ann. N. Y. Acad. Sci. 1079: 1-8.

Saccucci P, Del DE, Rapini N, Verrotti A, et al. (2008). Association between PTPN22 C1858T and type 1 diabetes: a replication in continental Italy. Tissue Antigens 71: 234-237.

Santiago JL, Martínez A, de la Calle H, Fernández-Arquero M, et al. (2007). Susceptibility to type 1 diabetes conferred by the PTPN22 C1858T polymorphism in the Spanish population. BMC Med. Genet. 8: 54.

Smyth D, Cooper JD, Collins JE, Heward JM, et al. (2004). Replication of an association between the lymphoid tyrosine phosphatase locus (LYP/PTPN22) with type 1 diabetes, and evidence for its role as a general autoimmunity locus. Diabetes 53: 3020-3023.

Smyth DJ, Cooper JD, Howson JM, Walker NM, et al. (2008). PTPN22 Trp620 explains the association of chromosome $1 \mathrm{p} 13$ with type 1 diabetes and shows a statistical interaction with HLA class II genotypes. Diabetes 57: 1730-1737.

Steck AK, Liu SY, McFann K, Barriga KJ, et al. (2006). Association of the PTPN22/LYP gene with type 1 diabetes. Pediatr. Diabetes 7: 274-278.

Stene LC, Rønningen KS, Bjørnvold M, Undlien DE, et al. (2010). An inverse association between history of childhood eczema and subsequent risk of type 1 diabetes that is not likely to be explained by HLA-DQ, PTPN22, or CTLA4 polymorphisms. Pediatr. Diabetes 11: 386-393.

Tang S, Peng W, Wang C, Tang H, et al. (2012). Association of the PTPN22 gene (+1858C/T, $-1123 \mathrm{G} / \mathrm{C})$ polymorphisms with type 1 diabetes mellitus: a systematic review and meta-analysis. Diabetes Res. Clin. Pract. 97: 446-452.

Taniyama M, Maruyama T, Tozaki T, Nakano Y, et al. (2010). Association of PTPN22 haplotypes with type 1 diabetes in the Japanese population. Hum. Immunol. 71: 795-798.

Taylor LH, Twigg S, Worthington J, Emery P, et al. (2013). Metaanalysis of the association of smoking and PTPN22 R620W genotype on autoantibody status and radiological erosions in rheumatoid arthritis. J. Rheumatol. 40: 1048-1053.

Yang B, Houlberg K, Millward A and Demaine A (2004). Polymorphisms of chemokine and chemokine receptor genes in type 1 diabetes mellitus and its complications. Cytokine 26: 114-121.

Yu X, Sun JP, He Y, Guo X, et al. (2007). Structure, inhibitor, and regulatory mechanism of Lyp, a lymphoid-specific tyrosine phosphatase implicated in autoimmune diseases. Proc. Natl. Acad. Sci. U. S. A. 104: 19767-19772.

Zhebrun D, Kudryashova Y, Babenko A, Maslyansky A, et al. (2011). Association of PTPN22 1858T/T genotype with type 1 diabetes, Graves' disease but not with rheumatoid arthritis in Russian population. Aging 3: 368-373.

Zheng W and She JX (2005). Genetic association between a lymphoid tyrosine phosphatase (PTPN22) and type 1 diabetes. Diabetes 54: 906-908.

Zhernakova A, Eerligh P, Wijmenga C, Barrera P, et al. (2005). Differential association of the PTPN22 coding variant with autoimmune diseases in a dutch population. Genes Immun. 6: 459-461.

Genetics and Molecular Research 14 (1): 63-68 (2015)

CFUNPEC-RP www.funpecrp.com.br 